\title{
Akcentowanie pograniczy w środkowoeuropejskim programie edukacyjnym in spe
}

\section{1. Źródła inspiracji}

Niniejszy tekst jest wynikiem próby włączania elementów holistycznej kosmoekologii (zob. np. Korpikiewicz 2006) do humanistycznej edukacji o pograniczach. Według Honoraty Korpikiewicz holistyczne pojmowanie „człowieka-Świata" opiera się na odrzuceniu w oglądzie rzeczywistości antropocentrycznej koncepcji „upodmiotowienia człowieka i uprzedmiotowienia Natury”. Ujawnia ono jednocześnie trudności ${ }^{1} \mathrm{w}$ zrozumieniu i analizie związków przyczynowo-skutkowych pomiędzy elementami Wszechświata, do których należą ludzie (Korpikiewicz 2001: 357). Skomplikowane sieci relacji między elementami Kosmosu są determinantami życia ludzi i innych istot. W moim przekonaniu te determinanty powinny być programowo wpisane w obszar edukacji humanistycznej choćby jako przesłanki obrazujące niedoskonałości (samo)poznania człowieka i jego twórczości (jak również twórczości nie-ludzi).

Koncepcja artykułu i jego tytuł powstały po lekturze zbioru Na pograniczu narodów i kultur. Polska - Europa - Ameryka wydanego w 2020 roku (Wróblewski, Janicki, oprac. 2020). Tom składa się z wyboru tekstów badawczych, eseistycznych i literackich publikowanych na łamach czasopisma „Akcent” od

1 Niektórzy badacze mówią nawet o niemożliwości poznania sieci związków Wszechświata (Korpikiewicz 2001: 357). 
momentu jego powstania w 1980 roku. Redaktor naczelny periodyku, a zarazem autor wstępu do antologii uznaje, że „[...] kwestia relacji międzykulturowych to najważniejszy problem, z jakim musi się uporać świat w XXI stuleciu”. I dodaje, że „szczególnie dotkliwie odczuwa to dzisiejsza Europa” (Wróblewski 2020: 6).

W związku z powyższą tezą Bogusław Wróblewski proponuje lekturę, w której zgromadzono „pionierskie wypowiedzi wybitnych polskich, europejskich i amerykańskich humanistów skoncentrowane wokół kwestii pogranicza kulturowego w jej najważniejszych aspektach" (Wróblewski 2020: 10). Podkreślenia wymaga fakt, że w tomie znaleźć można różne wypowiedzi o charakterze programowym dotyczące koncepcji odbioru kulturowych pograniczy. Należy do nich myśl z wierszowanego utworu ${ }^{\star * \star}$ Ryszarda Kapuścińskiego:

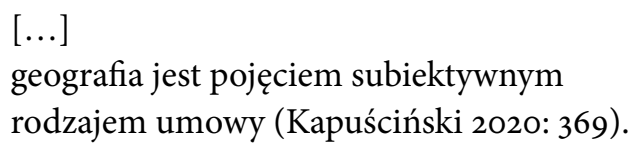

Ta literacka kontynuacja wizji Edwarda Saida mogłaby być mottem całego zbioru i innych opracowań skupionych na problematyce geografii wyobrażonej. Zastanawia, że we wstępie do antologii piśmiennictwa o środkowoeuropejskich kontaktach kulturowych nie ma refleksji nad kolonializmem i postkolonializmem. Autor wprowadzenia nie zapowiada nawet opublikowanego w tomie omówienia (Skórczewski 2020: 439-451) ważnego metodologicznie projektu Dyskurs postkolonialny we współczesnej literaturze i kulturze Europy Środkowo-Wschodniej (Bakuła i in., red. 2015). Być może Wróblewski nie odniósł się do problematyki postkolonialnej bez zamierzonych intencji, ale w ten sposób przypomniał o pułapkach oglądu świata z tej perspektywy. Precyzyjnie wyliczyła je Emilia Kledzik. Zwróciła ona także uwagę na fakt, że „sięgając po postkolonialne instrumentarium, trzeba pamiętać o ryzyku anachronizowania” (Kledzik 2015: 185).

Z pewnością teksty opublikowane w cytowanej monografii lubelskiej, pochodzące z przełomu XX i XXI wieku, stanowią świetny materiał dydaktyczny do konwersatoriów o sposobach odbioru i przedstawiania kultur pograniczy w świecie euroamerykańskim. Świadczą o tym już same tytuły niektórych z nich: Litwini i Polacy Tomasa Venclovy, Polska, Ukraina, Europa - między wyobraźniq a rzeczywistościq Mykoły Riabczuka, Tożsamość węgierska a Europa Środkowa, którego autorem jest Csaba G. Kiss, oraz Danuty Mostwin Emigrant na pograniczu kultur. Dwa eseje o Polakach $w$ Ameryce. Takie wypowiedzi ustawiają czytelnika w roli empatycznego interpretatora inności i pograniczności oraz krytycznego znawcy postaw etnocentrycznych. Przygotowują do badania zjawisk i procesów zachodzących na pograniczach. 
Prezentowany tom można odbierać jako swoisty podręcznik uczący analizowania kultur pograniczy, ale również czytać go jako świadectwo odbioru fenomenów występujących na styku kultur. Właśnie jako takie dwoiste dzieło stał się punktem wyjścia do rozważań proponowanych pod dyskusję w niniejszym artykule. Jak już wzmiankowano, zagadnieniem wiodącym jest w nim bowiem próba przedstawienia wstępnych założeń możliwych edukacyjnych dyskursów o pograniczach w ujęciu holistycznym. Dodajmy, że chodzi tu o ogląd zjawisk i ich analizę, które uwzględniają zależności i oddziaływania kultur w diachronii i synchronii ekosystemów (sic!).

\section{Modele oddziaływań i płynna pograniczność}

Wróblewski definiuje trzy modele wzajemnych oddziaływań

[...] różnych kultur, narodów, wyznań religijnych - czyli [...] różnych paradygmatów kulturowych [...]:

1. Konfrontacja. Systemy wartości (paradygmaty kulturowe) wchodzą ze sobą w kolizję, co w najlepszym razie oznacza izolację wzajemną, w najgorszym - prowadzi do otwartego, ostrego konfliktu, często związanego $\mathrm{z}$ dążeniem do fizycznego unicestwienia jednej ze stron. [...]

2. Osmoza albo dyfuzja - przenikanie. Niektóre wartości należące do paradygmatu «sąsiadów» zostają harmonijnie i trwale wmontowane w system wartości drugiej strony. [...]

3. Synergia. Wzmocnienie pewnych wartości obu systemów, które stają się konstytutywne dla ukształtowania nowego, spójnego paradygmatu, niewchodzącego w konflikt w żadnym $\mathrm{z}$ tych, z których czerpie, a nawet je wzmacniającego [...] (Wróblewski 2020: 9-10 $)^{2}$.

W dobie antropocenu i w kontekście dydaktyki holistycznej powyższe inspirujące rozróżnienie wymaga rozwinięcia. Problemem jest bowiem już sam wybór języka opisu światów pograniczy rozumianych jako:

a) każda relacja wewnątrzśrodowiskowa - ekosystemowa,

b) każda relacja międzykulturowa (Wróblewski 2020: 5-6).

W pierwszym ujęciu nawiązano do cybernetycznej definicji antropologa Gregory’ego Batesona uznającego istnienie człowieka jako części środowiska;

2 W przypadku synergii Wróblewski odwołuje się do pojęcia „trzeciej wartości” wprowadzonego przez Mostwin - badaczkę emigracji polskiej w Stanach Zjednoczonych. To wartości, które powstają w wyniku zetknięcia się różnych kultur. 
ekosystem to całość: „ «człowiek-i-środowisko», gdzie działają rozmaite obwody sprzężeń, a nie ma miejsca jednostronna kontrola czy determinacja, przez co w człowieku myśli «mózg, który jest częścią systemu obejmującego środowisko»" (cyt. za: Witkowski 20163). W takim układzie w świat humanistyczny immanentnie wpisane jest egzystowanie na płynnym pograniczu między tym, co indywidualne, a tym, co środowiskowe - ekosystemowe.

W doprecyzowaniu pojęcia płynnej pograniczności pomaga pytanie Przemysława Czaplińskiego, jakie znajduje się w wyjaśnieniu terminu posthumanizm:

Posthumanizm odchodzi [...] od klasycznej kwestii humanizmu „Czym jest człowiek?”, proponując pytanie: „W czym jest człowiek?”. Pytanie to należy rozumieć co najmniej trojako. Po pierwsze, odsyła ono bezpośrednio do aktualnego momentu historycznego, w którym człowiek (skoro tak wiele w nim i wokół niego uległo zmianie) musi zwątpić $\mathrm{w}$ dotychczasowe definicje, aby określić na nowo swoje usytuowanie w historii. Po drugie, kieruje ono ku uświadomieniu, że człowiek zawsze i wszędzie istnieje $\mathrm{w}$ sieciach relacji $\mathrm{z}$ innymi istotami ludzkimi i pozaludzkimi; w związku z tym pytanie: „W czym jest człowiek?” należy rozumieć jako postulat rozpoznania i badania układów oraz aktualnie w nich działających czynników sprawczych. Po trzecie, pytanie to oznacza, że właściwości uznawane dotąd wyłącznie za ludzkie (np. współpraca, komunikowanie się, rozumność, współodczuwanie, sprawczość) istnieją jedynie w sieciach - tam zaś znajdują się w ciągłym ruchu i występują jako właściwości relacyjne wielu istot (Czapliński 2017: 194).

Ta relacyjność interpretowana jako kategoria pograniczności wymaga analizy metodami, które rezygnują z antropocentrycznego przekonania o wyższości gatunku ludzkiego nad innymi bytami przyrody ożywionej i nieożywionej. Włączono tu - co oczywiste - myśl ekokrytyczną do dyskursu badań postzależnościowych. W tak rozumianym nurcie ekokrytyki istotą stają się:

a) krytyczne oglądy działalności człowieka dającego sobie prawo dominacji nad tym, co pozaludzkie, a więc analizy człowieka jako władcy świata, kolonizatora Kosmosu;

b) badania procesów zmian zachodzących w postrzeganiu przez człowieka swego miejsca w świecie (analizy postaw np. antropocentrycznej czy ekocentrycznej).

3 Przypis na podstawie tekstu Rafała Włodarczyka wykorzystującego pracę Lecha Witkowskiego Konteksty i elementy ekologii umystu, idei $i$ wychowania wedtug Gregory'ego Batesona (zob. Włodarczyk 2019: 15). 


\section{Natura i kolonializm. Terminologia przyrodoznawcza jako narzędzie opisu relacji na pograniczach}

Istotnym problemem edukacyjnym dotyczącym pograniczności wewnątrzśrodowiskowej jest fakt, że nierzadko w tekstach badawczych wejście człowieka w „bezludzką” dotąd naturę nie jest postrzegane jako zagarnięcie i proces przemocowy. Antropocentryczne postrzeganie działalności człowieka w środowisku wyklucza też interpretację jego poczynań z perspektywy świata nie-ludzi. Przykładem jest jedno z dookreśleń kolonializmu znajdujące się w interesującym artykule Rafała Włodarczyka Kolonizacja jako kategoria analityczna komparatystyki pedagogicznej:

Warto zatem podkreślić, że kolonizacja choć nie pozostaje nigdy neutralna, nie jest nierozerwalnie związana z przemocą i przyjmuje również inne formy niż te właściwe kolonializmowi, na co w jej długiej i rozległej historii można znaleźć wiele przykładów: począwszy od zasiedlania ziemi niczyjej, zakładania nowych osad przez ludność przybyłą z bliższych lub dalszych stron na terenach użytkowanych dotychczas w ograniczonym zakresie, przez uzależnienie od metropolii oddalonej od niej osady, miasta czy prowincji, sprowadzanie i osiedlanie obcej ludności przez rodzimych władców [...], przyjmowanie i lokowanie na osobnych zasadach w bezpośrednim sąsiedztwie danego społeczeństwa grup odrębnych etnicznie, religijnie czy kulturowo, przenoszących się, uchodzących, wygnanych, przesiedlonych, uprowadzonych, zesłanych z innych części świata, po podbój i zasiedlenie ziem wcześniej zajętych wraz $\mathrm{z}$ narzuceniem opanowanej ludności własnych standardów w wybranych dziedzinach życia lub w każdej z nich (Włodarczyk 2019: 20, wyróż. - K.T.).

Definiowanie w powyższym cytacie kolonizacji jako procesu zajmowania przez człowieka terenów przyrodniczych ma charakter antropocentryczny. Wynika to ze sformułowania: „zasiedlanie ziemi niczyjej”, w którym „niczyjej” oznacza 'niezamieszkałej przez ludzi'. Perspektywa posthumanizmu natomiast implikuje ogląd człowieka jako bytu egzystującego w układach z innymi bytami przyrody ożywionej i nieożywionej. $Z$ tego punktu widzenia należałoby do języka opisu takich relacji pogranicznych wprowadzić znane z języka biologii terminy określające sposoby współfunkcjonowania organizmów w ekosystemie. Do rozszerzenia znaczeń nomenklatury nauk przyrodniczych skłania m.in. cytowany podział międzykulturowy Wróblewskiego, również czerpiącego $\mathrm{z}$ określeń $\mathrm{z}$ tej dziedziny wiedzy. 
Wymienione poniżej przyrodnicze terminy uzupełniono wyjaśnieniami, w których głównym bohaterem jest człowiek egzystujący w danym układzie. Wyróżnia się m.in. następujące formy współbytowania:

- symbioza - rodzaj współżycia, w którym człowiek oraz inne byty ludzkie i nie-ludzkie czerpią obopólne korzyści;

- pasożytnictwo - wykorzystywanie istoty ludzkiej i nie-ludzkiej przez człowieka; człowiek-pasożyt szkodzi innemu bytowi;

- komensalizm - to układ, w którym człowiek jest komensalem, czyli czerpie korzyści z obecności innej istoty, która nic na tym nie traci;

- konkurencja - rodzaj egzystencji, w której człowiek konkuruje o dane dobra z innymi istotami ludzkimi i nie-ludzkimi;

- drapieżnictwo - człowiek-drapieżnik traktuje innych jako swoje ofiary, np. zabija dla korzyści;

- amensalizm - występuje wówczas, gdy czynności życiowe społeczności ludzkiej lub pojedynczego człowieka szkodzą innym istotom ${ }^{4}$, zjawisko charakterystyczne m.in. dla zjawiska zasiedlania terenów dotąd niezamieszkałych przez ludzi.

\section{Kolonizacja natury w literaturze pogranicza. Casus legendy założycielskiej}

Zastosowanie wyróżników przedstawionych we wcześniejszych akapitach do analizy tekstów literackich (i innych tekstów kultury) determinuje interpretacje z perspektywy bio- czy, szerzej, ekocentrycznej. Nierzadko w ten sposób znana lektura zyskuje nowe znaczenie. Przykładem mogą być fragmenty legendy o Janie i Cecylii z Nad Niemnem Elizy Orzeszkowej odczytywane jako tekst o ludziach pograniczy kolonizujących puszczę. Przytaczam cytat, by w pełni widoczne było uzasadnienie wprowadzenia języka biologii w interpretacji tego tekstu:

Z tej strony rzeki i z tamtej strony rzeki, na prawo i na lewo, naprzód i w tył, rosła jedna tylko puszcza. Jan i Cecylia upatrzyli sobie właśnie te miejsce, gdzie teraz ten pomnik stoi, a gdzie podtenczas stał dąb taki stary, co może i tysiąc lat miał wieku, bo w jego wydrążeniu bawoła skryć byłoby można, i pod tym dębem zbudowali sobie najpierwej chatę, czyli takąż numę bez pieca i komina, nędzną i smrodliwą. Od razu inszej zbudować nie mogli. Lepiej mówiąc, on zrąbywał drzewa, oprawiał

4 Rozróżnienia systemów współzależności znaleźć można w różnych opracowaniach z zakresu nauk przyrodniczych, zob. np. Weiner 2020. 
kłody i budował, a ona zbierała orzechy i dzikie jabłka, gotowała rybę, doiła bawolicę, którą on rychło sobie obłaskawił, naprawiała odzież, a gdy wieczór przyszedł i on położył się pod dębem, z oszczepem i łukiem napiętym przy boku, by zawsze od dzikiego zwierza się obronić, siadała przy jego głowie śpiewając i grając na harfie. [...] Wszystko tu było nie tak, jak teraz, ale okropniej i dziczej. [...] Prawda i to, że wiele rzeczy i stworzeń podtenczas człowiekowi do pomocy stało. Narzędzia do wszelakich robót i myślistw przynieśli z sobą albo różnym sposobem zrobili sobie, dobre i mocne. Las dawał dzikie jabłka, orzechy, jagody i grzyby; do rzeki po napój przybiegały jelenie, daniele i sarny, które ze stad wielkich łatwo ubijać było; u góry żył lud wiewiórek, a u dołu w gęstwinach skrywała się mnogość zajęcy, łasic i kun; w wodach mieszkały wydry i bobry domki sobie budowały. A trzeba było tylko wędę, sieć albo oszczep w rzekę zanurzyć, ażeby z niej wyłowić tyle ryb różnych, jakich już teraz wcale ona nie ma. Do tego i lubości bywało tu nadmiar. Słowicze śpiewy umilały noce, a jaskółcze i gołębie gminy same przez się szukały przytułku pod dachem numy. Podczas ze sznura żurawi spadł jeden i łaskawie ostał już towarzyszem człowieka; podczas płochliwa sarna ugłaskać się pozwoliła, wiernie potem chodząc przy boku swej pani. Wszelako tam bywało: ciężko i mile, straszno i bezpiecznie (Orzeszkowa 2009: 215-217).

W cytowanych partiach narracji z utworu Orzeszkowej występują zjawiska typowe dla kolonizacji. Można je scharakteryzować jako:

a) amensalizm - zagospodarowywanie ziemi przez ludzi, którzy zmieniają dotychczasowe środowisko i wypierają inne gatunki, zostało $\mathrm{w}$ tym fragmencie pokazane w sposób pośredni; narratora nie interesuje wpływ zmian środowiskowych na nie-ludzi, tego czytelnik może się jedynie domyślać;

b) drapieżnictwo („do rzeki po napój przybiegały jelenie, daniele i sarny, które ze stad wielkich łatwo ubijać było");

c) konkurencyjność (człowiek konkuruje o dobra i teren z nie-ludźmi);

d) komensalizm („Do tego i lubości bywało tu nadmiar. Słowicze śpiewy umilały noce, a jaskółcze i gołębie gminy same przez się szukały przytułku pod dachem numy");

e) symbioza („ze sznura żurawi spadł jeden i łaskawie ostał już towarzyszem człowieka"). 
Opis zasiedlania puszczy odczytywany jako kolonizacja ukazuje kolejną wartość utworu. Nadaje antropocentrycznej opowieści założycielskiej nowy wymiar - współtworzy narrację o ekosystemie pogranicza. Warto zwrócić uwagę, że czytanie biocentryczne upodmiotawia ludzi i nie-ludzi - wszystkie istoty występujące w tej opowieści o życiu mają ten sam status. Są bohaterami literackimi pierwszo-, drugo- lub trzecioplanowymi tego samego ekosystemu.

Ekocentryczne i holistyczne zarazem interpretowanie tekstów kultury, gdyby stało się częścią systemu edukacji środkowoeuropejskiej, stworzyłoby nową wspólną płaszczyznę uwrażliwienia na Innych: ludzi i nie-ludzi. Ujawniłoby zapewne też, wynikające $\mathrm{z}$ antropocentryzmu, dotychczasowe ograniczenia w analizie wielu dzieł. W Polsce pierwszą próbę wprowadzenia ekokrytyki do metodyki szkolnej stanowi opracowanie Literatura $i$ jej natury. Przewodnik ekokrytyczny dla nauczycieli i uczniów szkół średnich (Czapliński, Bednarek, Gostyński 2017). Nie wyeksponowano w nim jednak włączenia ekokrytyki w dyskurs postkolonialny i, szerzej, postzależnościowy.

\section{Kolonizacja jako determinant}

Pozostaje pytaniem otwartym, czy w ogóle jest możliwe wyjście człowieka z roli kolonizatora kosmosu. Czy nie jest tak, że tę rolę ludzi można tylko analizować i interpretować? I być może jedynie modyfikować? Innymi słowy: chyba nie ma ucieczki przed kolonizacją, jak tylko w inną kolonizację. Zwłaszcza jeśli uzna się, że Gombrowiczowską gębą jest również socjalizacja, która jest rodzajem kolonizacji mentalnej. Jej egzemplifikacją jest współczesna dominacja angielszczyzny. Tę hegemonię jako zjawisko ukazał z perspektywy nauk pedagogicznych Rafał Włodarczyk:

Dynamika konsolidacji ideologii edukacyjnych, ich zakorzenianie się w danej rzeczywistości społecznej czy tylko w grupach specjalistów i ekspertów oraz siła mobilizacji i oddziaływania na otoczenie, [...] w jakiś sposób zależą od nowości, oryginalności czy prawdziwości, jakie się z nimi wiążą czy jakie się im przypisuje, charyzmy i oddania sprawie liderów, jednak zadawalające rozumienie wskazanych czynników i procesów wydaje się nieosiągalne, jeśli nie uwzględni ono ich społeczno-historycznych uwarunkowań. Za przykład takiego uwarunkowania, które odgrywa istotną rolę w przekładzie i migracji idei, koncepcji i rozwiązań z odmiennych kulturowo obszarów, a co za tym idzie w kształtowaniu tożsamości polskiej pedagogiki, może posłużyć progresja znaczenia i statusu języka angielskiego, która w ostatnich 
trzydziestu latach zaznaczyła się wzmacnianiem dominacji w miejscowych środowiskach akademickich, jak również poza nimi. [...] Polskojęzyczne książki i artykuły, nie tylko same przekłady zdają się świadczyć, że migracja idei sformułowanych oryginalnie w językach narodowych na grunt rodzimej pedagogiki nie rozkłada się równomiernie. Badania komparatystyczne naszego aktualnego stanu recepcji za pewne pozwoliłyby zarysować tu pewną gradację: prawdopodobieństwo migracji koncepcji ogłoszonych w języku rosyjskim, portugalskim, japońskim, mandaryńskim czy hindi samo zróżnicowane, jest w jakimś stopniu mniejsze niż w języku niemieckim, francuskim czy włoskim, a wszystkie te możliwe wpływy dystansuje język angielski. Rozpowszechnieniu znajomości języka angielskiego wśród polskich pedagogów zdaje się towarzyszyć wygasanie kompetencji potrzebnych do odtwarzania stanu i kierunków rozwoju badań pedagogiki niemieckiej oraz zainteresowania rosyjskojęzycznymi publikacjami (Włodarczyk 2019: 16).

Angielski jako język przekazu międzykulturowego jest także charakterystyczny dla Europy Środkowo-Wschodniej. Wcześniej - jak wiadomo - dominowały w tym obszarze inne języki: rosyjski czy niemiecki (historia Austro-Węgier). Warto w tym miejscu choćby wspomnieć o szkicu Janusza Golca z tomu $\mathrm{Na}$ pograniczu narodów i kultur zatytułowanym Europa czy pót-Azja? Granice kultury według Karla Emila Franzosa. Została w nim ukazana germanocentryczność żydowskiego pisarza z austro-węgierskiej Galicji. Mianem „Halb-Asien” określił on to, co dla niego gorsze, czyli nie niemieckie, utrwalając w ten sposób mity i stereotypy kulturowe (Golec 2020: 299-306). Każdy język osobniczy wikła człowieka w zależność, od której nie może się on uwolnić. Szczególne dylematy zależnościowe mogą mieć ludzie dwu- i wielojęzyczni, egzystujący na pograniczach kulturowych, np. austro-węgierskich.

Trudno mówić zatem o historii obszaru pograniczy bez uwzględniania językowego aspektu kolonizacyjnego5. Badaczka mowy pograniczy - Anna Zielińska - wprowadziła do jej analizy socjologiczne określenia: języka jako piętna i przemocy symbolicznej (Zielińska 2013: 242-255). Przypadki takich ludzi jak pisarz zaprezentowany w tekście Golca to przykłady ofiar kolonialnej przemocy symbolicznej, które często nie były w stanie nawet dostrzec, że są ofiarami.

5 Zaskakuje, że w polskiej refleksji badawczej nad nowymi pograniczami niemiecko-polskimi (powstałymi po 1945) tak niewiele jest prac, których autorzy widzą potrzebę uwolnienia języka naukowego od wpływów języka mitu „ziem odzyskanych” (Taborska 2017: 19-20). 
Podsumowując, wracam do definicji pograniczy rozumianych jako relacje międzykulturowe. Sądzę bowiem, że warto zmodyfikować zaproponowany przez Wróblewskiego schemat paradygmatów wzajemnego oddziaływania różnych kultur, by dostosować go do zaproponowanej w tym tekście klasyfikacji zaczerpniętej $z$ terminologii nauk przyrodniczych.

Model konfrontacyjny można zatem uznać - w zależności od jego typu - za odmianę konkurencji, drapieżnictwa, pasożytnictwa czy amensalizmu. Dyfuzja, czyli osmoza, staje się w tym układzie formą komensalizmu, natomiast synergia rodzajem symbiozy. W ten sposób określenia współistnienia społeczności na pograniczach kulturowych stają się określeniami ekokrytycznymi i w konsekwencji - jak się zdaje - ewokują holistyczną refleksję nad egzystowaniem człowieka nie tylko w mikrokosmosie środkowoeuropejskim. Mogą być też one pomocne w uwalnianiu języka od mitycznych i stereotypowych określeń kulturowych.

Niniejszy artykuł to szkicowa propozycja wprowadzenia uzupełnień do edukacyjnego przedstawiania sposobów oglądu pograniczy, dających możliwość większego wyboru metod interpretowania rzeczywistości, jak również nowego odczytywania literatury i innych dzieł ludzi oraz nie-ludzi. Każde z zaprezentowanych tu zagadnień mogłoby stać się przedmiotem dalszych rozważań i - co równie istotne - polemik.

Nie ma jednak wątpliwości, że teksty powstałe na pograniczu narodów i kultur są źródłem inspiracji i wymagają nowych perspektyw odbiorczych. Świadczy o tym także tom Wschodniej Fundacji Kultury „Akcent”, dzięki lekturze którego powstał ten szkic.

\section{| Bibliografia}

Bakuła Bogusław i in., red. (2015), Dyskurs postkolonialny we wspótczesnej literaturze i kulturze Europy Środkowo-Wschodniej, Biblioteka Porównań, Poznań.

Czapliński Przemysław, Bednarek Joanna B., Gostyński Dawid (2017), Literatura i jej natury. Przewodnik ekokrytyczny dla nauczycieli i uczniów szkót średnich, Wydawnictwo Rys, Poznań.

Czapliński Przemysław (2017), Posthumanizm, w: Czapliński Przemysław, Bednarek Joanna B., Gostyński Dawid, Literatura i jej natury. Przewodnik ekokrytyczny dla nauczycieli i uczniów szkót średnich, Wydawnictwo Rys, Poznań, S.192-195. 
Fiedorczuk Julia (2015), Cyborg w ogrodzie. Wprowadzenie do ekokrytyki, Wydawnictwo Naukowe Katedra, Gdańsk.

Golec Janusz (2020), Europa czy pót-Azja? Granice kultury według Karla Emila Franzosa, w: Na pograniczu narodów i kultur. Polska - Europa - Ameryka, oprac. Bogusław Wróblewski, Łukasz Janicki, Czytelnik, Wschodnia Fundacja Kultury „Akcent”, Warszawa-Lublin, s. 299-306.

Kapuściński Ryszard (2020), wiersze, w: Na pograniczu narodów i kultur. Polska Europa - Ameryka, oprac. Bogusław Wróblewski, Łukasz Janicki, Czytelnik, Wschodnia Fundacja Kultury „Akcent”, Warszawa-Lublin, s. 365-369.

Kledzik Emilia (2015), Polski postkolonialazim. Strategie udomowienia, w:

Dyskurs postkolonialny we wspótczesnej literaturze i kulturze Europy Środkowo-Wschodniej, red. Bogusław Bakuła i in., Biblioteka Porównań, Poznań, s. $183-203$.

Korpikiewicz Honorata (2001), Wpisani w Naturę. Spojrzenie holistyczne, w: Człowiek - zwierze - cywilizacja. Aspekt humanistyczny, red. Honorata Korpikiewicz, Prodruk, Poznań, s. 356-373.

Korpikiewicz Honorata (2002), Kosmoekologia z elementami etyki holistycznej, Prodruk, Poznań.

Korpikiewicz Honorata (2006), Kosmoekologia - obraz zjawisk, Wydawnictwo Naukowe UAM, Poznań.

Korpikiewicz Honorata (2011), Biokomunikacja. Jak zwierzęta porozumiewają się ze światem, Wydawnictwo Naukowe UAM, Poznań.

Orzeszkowa Eliza (2009), Nad Niemnem, t. 1, Zakład Narodowy im. Ossolińskich, Wrocław.

Skórczewski Dariusz (2020), Perspektywa postkolonialna w studiach na temat Europy Środkowo-Wschodniej, w: Na pograniczu narodów i kultur. PolskaEuropa - Ameryka, oprac. Bogusław Wróblewski, Łukasz Janicki, Czytelnik, Wschodnia Fundacja Kultury „Akcent”, Warszawa-Lublin, s. 439-451.

Taborska Katarzyna (2017), Literatura miejsca. Piśmiennictwo postlandsberskie, Wydawnictwo Naukowe AJP, Gorzów Wielkopolski.

Weiner January (2020), Życie i ewolucja biosfery. Podręcznik ekologii ogólnej, PWN, Warszawa.

Włodarczyk Rafał (2019), Kolonizacja jako kategoria analityczna komparatystyki pedagogicznej, „Przegląd Pedagogiczny”, nr 2, s. 9-23.

Wróblewski Bogusław (2020), Pogranicze - intuicje i racje, w: Na pograniczu narodów i kultur. Polska - Europa - Ameryka, oprac. Bogusław Wróblewski, Łukasz Janicki, Czytelnik, Wschodnia Fundacja Kultury „Akcent”, Warszawa-Lublin, s. 5-12. 
Wróblewski Bogusław, Janicki Łukasz, oprac. (2020), Na pograniczu narodów i kultur. Polska - Europa - Ameryka, Czytelnik, Wschodnia Fundacja Kultury „Akcent”, Warszawa-Lublin.

Zielińska Anna (2013), Język jako piętno, w: taż, Mowa pogranicza. Studium o językach i tożsamościach $w$ rejonie lubuskim, Slawistyczny Ośrodek Wydawniczy, Warszawa, s. 238-255.

\section{| Abstrakt}

\section{KATARZyNA TABORSKA}

Akcentowanie pograniczy w środkowoeuropejskim programie edukacyjnym in spe

Artykuł stanowi próbę włączenia do humanistycznej edukacji o pograniczach elementów kosmoekologii. Jego powstanie zainspirowała lektura zbioru Na pograniczu narodów i kultur. Polska - Europa - Ameryka (oprac. B. Wróblewski, Ł. Janicki, Warszawa-Lublin 2020). Celem jest przedstawienie wstępnych założeń możliwych edukacyjnych dyskursów o pograniczach w ujęciu holistycznym, które uwzględnia zależności oraz oddziaływania kultur w diachronii i synchronii ekosystemów. W tekście zaproponowano m.in. wprowadzenie terminologii z zakresu przyrodoznawstwa jako narzędzia opisu relacji na pograniczach. Przedstawiono w nim również refleksje dotyczące płynnych pograniczy wewnątrzśrodowiskowych oraz ekokrytyczne ujęcie kolonizacji.

Słowa kluczowe: antropocen, holizm, posthumanizm, pogranicza wewnątrzśrodowiskowe, pogranicza kulturowe, ekocentryczna edukacja humanistyczna

\section{| Abstract}

KATARZYNA TABORSKA

Emphasizing the Borderlands in a Future Central European Educational Programme

The present paper is an attempt at including elements of cosmoecology in humanistic education on borderlands. The composition of the paper was inspired by the reading of the edited volume Na pograniczu narodów i kultur. Polska - Europa - Ameryka [On the borderlands of nations and cultures. Poland - Europe-America] (eds. B. 
Wróblewski, Ł. Janicki, Warszawa-Lublin 2020). The goal of the article is to present preliminary assumptions for possible educational discourses on the borderlands in a holistic approach, which will provide for the dependencies and mutual influence of cultures in the diachrony and synchrony of ecosystems. The author puts forward the introduction of terminology related to natural sciences as a tool for describing relationships on borderlands and presents her reflections on liquid intra-environmental borderlands as well as an ecocritical approach to colonization.

Keywords: Anthropocene, holism, post-humanism, intra-environmental borderlands, cultural borderlands, eco-centric humanistic education

\section{| Biogram}

Katarzyna Taborska - dr hab. prof. AJP; wykłada na Wydziale Humanistycznym Akademii im. Jakuba z Paradyża w Gorzowie Wielkopolskim. Kieruje Pracownią Badań nad Literaturą i Czasopiśmiennictwem Pogranicza, która funkcjonuje w ramach Akademickiego Centrum Badań Euroregionalnych - jednostki uczelnianej działającej pod patronatem Instytutu Slawistyki PAN. Bada różnojęzyczną literaturą pograniczy; interesuje się również zagadnieniami polimedialności. Jest autorką kilkudziesięciu publikacji, w tym książek: Krytyka jako autokreacja. Wizerunki Marcela Reicha-Ranickiego (2008), Lektury polimedialności. Studium odbioru (2015), Literatura miejsca. Piśmiennictwo postlandsberskie (wyd. 1: 2017, wyd. 2: 2019). Współredagowała m.in. cykl Literatura $w$ mediach. Media $w$ literaturze (2010, 2012, 2014, 2018); tom Pogranicze wschodnie i zachodnie (2015) oraz zbiór Literatura zza granic Polski. Diagnozy - prognozy - prowokacje. Wschód (2019).

E-mail: katarzynataborska@wp.pl

ORCID: 00oo-0002-0038-9488 